\title{
The Best Family Business Boards Embrace Candor and 'Necessary Endings'
}

\author{
Claudia Binz Astrachan (Lucerne University of Applied Sciences and Arts) \\ Joseph Astrachan (Kennesaw State University) \\ Hermut Kormann (Zeppelin University)
}

KEYWORDS: Management, Strategy, Family Business, Board of directors.

\section{Second of a two-part series}

From our studies evaluating the effectiveness of boards at family firms, we've seen first-hand how strong boards can help family businesses be more successful. In our experience, we've seen four things that successful family businesses and their boards do well:

1. Clarify Competencies and Roles

2. Manage Group Dynamics and Nurture Strong Relationships

3. Promote Candor and Transparency and Leverage Setting the Agenda

4. Embrace Necessary Endings

In a past article(https://familybusiness.org/content/fourthings-that-the-best-family-business-boards-do-well)we focused on the first two best practices, dealing with board member competence and role clarity, and the need to manage group dynamics and nurture relationships among board members and beyond.

This article focuses on the other two.

\section{Promote Candor and Transparency, and Leverage Setting the Agenda}

We often come across boards whose members gush over each other's personalities or contributions, or about the absence of conflict during board meetings and how well they all get along. That's great, but often it's not the whole story. Through our work with family firms we've learned that lots of private backroom conversations take place between board members and the Chair, who then takes it to the CEO or other members of the executive team.

While this politicking may have some advantages, constantly avoiding confrontation prevents the entire board from having difficult conversations that could strengthen their relationships and improve boardroom conversations in the long run.

Consider using your board agenda to encourage candor and transparency. Set your agenda to prioritize key strategic success factors, independent of actual developments or events. Unless you're responding to big mistakes and crises, if events drive your agenda it usually means means you're addressing systemic issues too late.

Think about how much time your board spends discussing the company's quarterly financial results, such as whether your sales are above or below budget. While that's important, this time would be much better used if the board challenged management's thinking and focused them on strategic priorities. For example, has your management proposed to review market share growth (or loss) regularly, or suggested an annual report on "Innovation and business development initiatives"?

You can see that the board agenda can be an important instrument for improving candor and transparency, and the overall board process. Management shouldn't set the tone for the agenda, although this often happens. All the critical items should be prioritized on the agenda and addressed regularly -- for example, middle management turnover, quality indicators, market share, image with customers, investment in innovation and upgrades to the business model.

\section{Takeaway}

Candor is essential in boosting the value of board room discussions. Make sure to allow room for difficult conversations - they almost always take longer than estimated. The Chair should gently re-direct any
Copyright $@ 2021$ The Authors. Entrepreneur \& Innovation Exchange is published at EIX.org. This is an open access article under the terms of the Creative Commons Attribution-NoDerivs License, which permits use and distribution in any medium, provided the original work is properly cited and no modifications or adaptations are made. View EIX.org Authorship Terms at https://eix.org/terms
FamilyBusiness 
backroom conversations to the boardroom. Interestingly, backroom conversations are the outcome of agendas that are too tightly scheduled, which leads to certain conversations being consistently pushed out and this goes straight to agenda setting. Take a moment to think about the topics that have repeatedly been kicked off the agenda - most boards have them (typically the last items on the agenda). If they are consistently postponed without consequence, they may not need to be an agenda item to begin with. If they are postponed and find their way back onto the agenda in a different shape, a backroom conversation has taken place. Make sure to leverage your board agenda: Are you discussing the right things, at the right time, with the right people, at the right altitude? How much time do you dedicate to talking about the past and the present versus the future - and do you engage in scenario planning? And lastly, the general rule for agenda setting is all board members should have equal time per topic to talk. Set guidelines for how much time individuals and the group should spend on a topic, and prioritize putting important strategic topics at the top of the agenda. In short, use your specified meeting time to maximum advantage.

\section{Reflection Questions}

- Does your board frequently engage in backroom conversations? Which topics are typically addressed, and maybe resolved outside of the boardroom?

- Are all board members equally comfortable with expressing their views with candor?

- How do the board and management deal with pushback and controversy? Should we improve our ability to deal with and provide constructive feedback?

- Do we leverage our agenda-setting process in a way that allows us to maximize our board's value?

\section{Embrace Necessary Endings}

Dr. Henry Cloud's book, in his book "Necessary Endings," states that "life generates too much." We firmly believe that we generally have too many opportunities, too many relationships, too many options - and we find it very hard to "prune the rose bush" by ending some of these engagements.
Many owners and board chairs struggle with this exact problem: We know that certain board members are underperforming or past their prime, but we shy away from the difficult conversation that leads to the board member's departure. We may be loyal to their past contributions. We may admire them personally. We may be reluctant to transition board members who care about the family and the business. Or, we may remain hopeful that they'll turn around and prove their worth to us after all.

One of us recently had a conversation with the owner of a large third-generation family business in the US. She mentioned that one board member had not added value for a while. She knows his wife and family and appreciates his years of service to the board and the company -- and that explains her reluctance to ask him to step down. For most people, knowing the right thing to do and doing the right thing are entirely different things. Acknowledging that doing the right thing for the collective may well mean hurting individual(s) along the way is a tough pill to swallow. But as Cloud writes in his book: "There is a difference between hurt and harm." Harm is damaging someone, while hurting someone may simply be a consequence of facing hard, but necessary truths.

Another important point: Many family businesses we work with have defined director tenures, as well as age limits - usually around 72 or 75 years. Without the right guidelines, you risk family directors (in particular) serving for 30 or more years. It is better specify a reelection period, with a maximum of perhaps 12 to 16 years. Of course, if you have a truly indispensable board member, shareholders can vote with a (super) majority vote to extend their tenure past the agreed-upon limit. From our experience, annual re-elections or elections for a regular time period - usually three to four years also work well. Annual re-elections may sound tedious, but, much like board evaluations, they remind board members that they are being held accountable and motivate them to improve.

\section{Takeaway}

Don't postpone a necessary ending. We know one CEO who often says, "I've never fired anyone too soon." You are not doing your board, your family, or the board member in question any favors by prolonging the inevitable. They very likely know they are not performing the way they should be -- and if they're oblivious to their lack of contributions, that's even worse. You owe it to 
the other board members, and the company, to select someone for the board who contributes at a high level.

\section{Reflection Questions}

- Have you been waiting for any director - family and non-family alike - to retire, rather than proactively asking them to step down?

- Do you have a general tendency to prolong projects or relationships past their time? Why are you hesitant to end things?

- Going forward, what structural changes (e.g., term limits, qualifying requirements, code of conduct) can you make so that "necessary endings" are easier for yourself, your board, your company, and your family?

\section{Final Thoughts}

Boards can be powerful instruments to help family business owners and leaders reach and surpass their objectives, but they are often under-leveraged. It takes time and money to put a great board together, to keep it going and to maintain and nurture relationships among board members and between the board and outside constituencies.

Regular board assessments - either annually or biannually -- signal that family leaders will hold the board accountable in the same way they hold management accountable. Opt for a longer timeframe if the assessments begin to feel like a cumbersome mandatory routine. Assessments should create space for necessary conversations among board members and give each board member a voice in identifying what makes or breaks the board.

And while external reviews can provide an objective point of view, you don't need to hire an outsider to assess your board: Many self-assessment tools (some of them available for free) provide valuable insights into board effectiveness (e.g., National Association of Corporate Directors NACD, boardroommetrics.com). Such a self-assessment can be an invaluable first step towards improving the quality and contribution of your board and might give you some initial insights as to what works - and what doesn't.

Board members sign up to serve on your board because they want to support you in making the right decisions for your business. Allow them to contribute fully, by making sure that board members are competent and trust one another. Encourage candid discussions, and ask board members who no longer contribute to step down. You might be surprised how, by simply addressing the desire to assess and improve board effectiveness, conversations start to happen.

\section{Acknowledgements}

We want to thank Prof. Dr. Kim Eddleston and Prof. Dr. Massimo Baù for their critical and constructive reviews of this contribution. 